\title{
Short Review of Climate Change in Support of Greta Thunberg and Fridays for Future
}

\author{
Rainer W. Kühne \\ Bürgerstr. 4, 38118 Braunschweig, Germany \\ kuehne70@gmx.de
}

\begin{abstract}
I review the evidence of natural climate change as given by the Greenland ice core data of the past 120,000 years and the Antarctica ice core data of the past 900,000 years. These data show that the atmospheric carbon dioxide concentration newer exceeded $300 \mathrm{ppm}$ (parts per million by volume) during the 650,000 years which preceded AD 1900. Only around 1900 did the concentration reach 300 ppm. Afterwards it increased continuously until the present value of over 400 ppm, where since AD 2000 it increases by 2 ppm per year. I predict that within the next one hundred years the global temperature will increase by further $3.6^{\circ} \mathrm{C}$ only because of the carbon dioxide concentration that is already at present in the atmosphere.
\end{abstract}

\section{Keywords}

ice age, carbon dioxide, greenhouse gas, global warming, climate change, Hothouse Earth, Anthropocene

\section{Introduction}

Swedish climate activist Greta Thunberg started her Skolstrejk för Klimatet on 20 August 2018 at the Mynttorget in her hometown Stockholm. Her activity inspired the weekly demonstrations of Fridays for Future which started in The Hague (The Netherlands) on 4 September 2018 and in Berlin (Germany) on 14 September 2018. These activities found world-wide interest by the mass media and will become the main subject of political discourse. The 2021 election in Germany will be dominated by this subject. Leftist parties will require decisive measures against a further man-made climate change, whereas rightwing parties will deny that there is a man-made climate change. The motivation of this paper is to review the main scientific works that argue for a natural climate change during the past 900,000 years and demonstrate the clear connection between atmospheric carbon dioxide concentration and atmospheric temperature. The present carbon dioxide concentration of more than 400 ppm (parts per million by volume) is clearly man-made and higher than the natural concentration which newer exceeded 300 ppm during the 650,000 years before the end of the 19th century.

\section{Evidence of Climate Change}

The global temperature of the present atmosphere has been measured directly since AD 1880 by using thermometers. The temperature variations of the ancient atmosphere cannot be measured directly. An indirect measurement can be made by examining the isotopic ratios of the hydrogen (deuterium concentration) and oxygen (oxygen-18 isotope concentration) of the water ice deep within the ice shields of Greenland and Antarctica. 
The higher the deuterium and oxygen-18 concentration, the higher the temperature. For the examined temperature intervals the difference in the isotopic ratio concentration is directly proportional to the temperature difference.

The atmospheric carbon dioxide concentration has been measured precisely and continuously since AD 1958. The carbon dioxide concentration of the ancient atmosphere is measured indirectly by determining the carbon dioxide concentration of air bubbles trapped within the deep ice of Antarctica.

The drill site of the North Greenland Ice Core Project (NGRIP) is located at $75.10^{\circ} \mathrm{N}$, $42.32^{\circ} \mathrm{W}$. Measurements of the oxygen-18 content of the ice showed the air temperature variation during the past 120,000 years. This time span includes the entire Holocene (the present warm phase of the past 11,700 years) and the entire last glaciation (called either Würm, Weichsel, Waldai or Wisconsin glaciation). The data show a number of minor warm phases (interstadials) during the last ice age [1].

The drill site of the European Project for Ice Coring in Antarctica (EPICA) at Dome Concordia is located at $75^{\circ} 06^{\prime} \mathrm{S}, 123^{\circ} 21^{\prime} \mathrm{E}$. Measurements of the deuterium concentration of the ice showed the air temperature variation during the past 900,000 years. This time span includes a number of ice ages (glacials) and warm phases (interglacials). The data show that the mean air temperature of the Antarctica site varied during the preceding 800,000 years by $15^{\circ} \mathrm{C}$. The minima were reached during the ice ages, the maxima during the last five interglacials. Comparison of the Antarctica data by EPICA with the Greenland data by NGRIP shows that all of the 24 interstadials during the last ice age occurred simultaneously in Antarctica and Greenland and that the shapes of the two temperature curves are very similar [2]. So the long-term climate change is global.

A measurement of the carbon dioxide concentration of the air bubbles trapped in the EPICA Dome Concordia ice core shows that for the preceding 650,000 years the curves for the carbon dioxide concentration and the air temperature (as measured by the deuterium concentration) are similar in shape. The maxima of the carbon dioxide concentration coincide with the relatively short interglacials and the weaker maxima coincide with the interstadials. During the entire 650,000 years the carbon dioxide concentration varied between 175 and 300 ppm [3].

A more precise analysis showed that an increasing carbon dioxide concentration preceded global warming during the last deglaciation. The concentration increased from $190 \mathrm{ppm}$ during the Oldest Dryas (20,000 years ago) through the Bölling, Older Dryas, Alleröd, Younger Dryas, until the early Holocene to $270 \mathrm{ppm}$ (10,000 years ago) [4]. The interpretation is that the increment of the greenhouse gas carbon dioxide was the main cause for the deglaciation of the last ice age and perhaps also of the other ice ages.

The drill site of the Taylor Dome in Antarctica is located at $77^{\circ} 48^{\prime} \mathrm{S}, 158^{\circ} 43^{\prime} \mathrm{E}$. Analysis of the ice core data showed that the carbon dioxide concentration dropped from $285 \mathrm{ppm}$ in $A D 1550$ (that is $400 \mathrm{BP}$, where zero before present is equal to AD 1950) to $275 \mathrm{ppm}$ in $A D$ 1600 (350 BP). This low value remained constant for the following 200 years, i.e. until AD 1800 [5]. The time period between AD 1600 and 1800 corresponds to the coolest time of the Little Ice Age, when the temperature in Central Europe decreased by 1.0 to $1.5^{\circ} \mathrm{C}$ according to indirect estimates based on the altitude of the tree line in the Alps.

The drill site of the Polar Ice Coring Office at Siple Station in Antarctica is located at $75^{\circ} 55^{\prime} \mathrm{S}, 83^{\circ} 55^{\prime} \mathrm{W}$. Measurements of the carbon dioxide concentration of the air bubbles 
trapped in the ice core showed that it increased from $279 \mathrm{ppm}$ in AD 1745 to $280 \mathrm{ppm}$ in AD 1806, to $297 \mathrm{ppm}$ in AD 1894, to $311 \mathrm{ppm}$ in AD 1949, to $328 \mathrm{ppm}$ in AD 1972 [6].

Precise and continuous measurements of the atmospheric carbon dioxide concentration began in AD 1958 and show a continuous increment from 315 ppm in 1958 [6] to 331 ppm in 1975 , to $369 \mathrm{ppm}$ in 2000 , to $379 \mathrm{ppm}$ in 2005 [7].

\section{Interpretation}

Taken together, all these data show:

An increment of the atmospheric concentration of carbon dioxide preceded global warming during the last deglaciation and was probably its main cause. A decrement of the atmospheric carbon dioxide concentration caused the cooling of the Little Ice Age which began in AD 1600, led to crop failure and turmoils in Europe and finally to the Thirty Years' War 1618-1648.

A variation of the carbon dioxide concentration by $125 \mathrm{ppm}$ [3] leads to a temperature variation of $15^{\circ} \mathrm{C}$ [2] in Antarctica, as shown by the data for the preceding 650,000 years.

A variation of the carbon dioxide concentration by $10 \mathrm{ppm}$ [5] leads to a temperature variation of $1.25^{\circ} \mathrm{C}$ in Europe, as shown by the data for the Little Ice Age $1600-1800$.

A variation of the carbon dioxide content by $75 \mathrm{ppm}$ leads to a global temperature variation of $3.5^{\circ} \mathrm{C}$, as shown by the data for the last deglaciation, between 20,000 and 10,000 years ago [8].

So an increment of the atmospheric carbon dioxide concentration by $100 \mathrm{ppm}$ would cause an increment of continental temperature (Antarctica and Central Europe) by $12^{\circ} \mathrm{C}$ and an increment of global temperature by $4.7^{\circ} \mathrm{C}$.

During the past 140 years, from AD 1880 to AD 2019, the atmospheric carbon dioxide concentration has increased by more than $100 \mathrm{ppm}$. This suggests that the global temperature increment between 1880 and 2019 by $1.1^{\circ} \mathrm{C}$ has only followed the carbon dioxide increment and that the global temperature will increase by further $3.6^{\circ} \mathrm{C}$ only because of the carbon dioxide concentration that is already at present in the atmosphere.

During the entire 650,000 years before the end of the 19th century the atmospheric carbon dioxide concentration has always been below $300 \mathrm{ppm}$ [3]. Afterwards it has always been above 300 ppm [6, 7]. Since AD 2000 the atmospheric carbon dioxide concentration increases by $2 \mathrm{ppm}$ per year and has already increased to above $400 \mathrm{ppm}$. This clearly shows that the increment of the atmospheric carbon dioxide concentration of the 20th and 21 st century is man-made.

For similar reasons Paul Crutzen defined the Anthropocene as the epoch after 1784 (the year of James Watt's design of the steam engine) which is characterized by growing manmade global concentrations of the greenhouse gases carbon dioxide and methane [9].

Clearly, the Earth atmosphere is at risk of becoming hotter than anything else known during the Pleistocene (age of mankind during the past 1.8 million years). This scenario became known as the Hothouse Earth [10]. 
Some authors suggested that there are only three years to safeguard our climate [11]. This motivated Greta Thunberg to start her Skolstrejk för Klimatet [12-16] and in turn the Fridays for Future demonstrations. These demonstrations were supported by Scientists for Future [17] whose program was signed by 26,800 scientists [18] and supported by additional 3,000 scientists [19].

\section{Conclusion}

Antarctic ice core data clearly show that an increment of atmospheric carbon dioxide concentration preceded global warming at the end of the last ice age and that a later decrement preceded global cooling at the start of the Little Ice Age AD 1600. The data further show that an increment of atmospheric carbon dioxide concentration by $100 \mathrm{ppm}$ (parts per million by volume) will be followed by a global temperature rise of $4.7^{\circ} \mathrm{C}$ and a continental temperature rise of $12^{\circ} \mathrm{C}$. I predict that within the next one hundred years the global temperature will rise by further $3.6^{\circ} \mathrm{C}$ only because of the carbon dioxide concentration that is already at present in the atmosphere.

\section{References}

[1] J. P. Steffensen et al.: High-resolution Greenland ice core data show abrupt climate change happens in few years. Science 321 (2008) 680-684.

[2] J. Jouzel et al.: Orbital and millennial Antarctic climate variability over the past 800,000 years. Science 317 (2007) 793-796.

[3] U. Siegenthaler et al.: Stable carbon cycle-climate relationship during the late Pleistocene. Science 310 (2005) 1313-1317.

[4] J. D. Shakun et al.: Global warming preceded by increasing carbon dioxide concentrations during the last deglaciation. Nature 484 (2012) 49-54.

[5] A. Indermühle et al.: Holocene carbon-cycle dynamics based on CO2 trapped in ice at Taylor Dome, Antarctica. Nature 398 (1999) 121-126.

[6] A. Neftel et al.: Evidence from polar ice cores for the increase in atmospheric CO2 in the past two centuries. Nature 315 (1985) 45-47.

[7] W. Steffen et al.: The Anthropocene: Are humans now overwhelming the great forces of nature. Ambio 36 (2007) 614-621.

[8] S. L. Lewis and M. A. Maslin: Defining the Anthropocene. Nature 519 (2015) 171-180.

[9] P. J. Crutzen: Geology of mankind. Nature 415 (2002) 23-23.

[10] W. Steffen et al.: Trajectories of the Earth system in the Anthropocene. Proceedings of the National Academy of Sciences of the United States of America 115 (2018) 8252-8259.

[11] C. Figueres et al.: Three years to safeguard our climate. Nature 546 (2017) 593-595.

[12] G. Thunberg: No One is Too Small to Make a Difference (Penguin, 2019).

[13] G. Thunberg: Cambiemos el mundo (Lumen, 2019). 
[14] G. Thunberg: Rejoignez-nous (Kero, 2019).

[15] G. Thunberg: Ich will, dass ihr in Panik geratet! Meine Reden zum Klimaschutz (Fischer, 2019).

[16] G. Thunberg: Canviem el mon \#vagapelclima (Destino, 2019).

[17] M. Warren: Thousands of scientists back kids' climate strike. Nature 567 (2019) 291292.

[18] R. W. Kühne: Climate change: The science behind Greta Thunberg and Fridays for Future. OSF Preprints (2019) doi:10.31219/osf.io/2n6kj.

[19] G. Hagedorn et al.: Concerns of young protesters are justified. Science 364 (2019) $139-140$. 